\title{
СТІЙКІСТЬ СОРТІВ СОЇ ДО ХВОРОБ В УМОВАХ ПРИРОДНОГО I ШТУЧНОГО ЗАРАЖЕННЯ РОСЛИН
}

С. В. Поліщук, С. І. Ляска

ННЦ «Інститут землеробства НААН»

Наведено результати досліджень стійкості сортів сої до хвороб в умовах природного і штучного зараження. Відпрацьована методика трьох етапної оцінки відбору стійких форм - джерел стійкості до хвороб (кутаста бактеріальна плямистість листя, пустульний бактеріоз, пероноспороз та септоріоз). У результаті імунологічної оцінки серед досліджуваних сортозразків сої виділено 32 сорти стабільно стійких до хвороб. стійкість

Соя, бактеріальна і грибна хвороба, штучне зараження, сорт,

В Україні актуальним є значне збільшення виробництва сільськогосподарської продукції. Особливе місце відводиться виробництву рослинного білка. Це обумовлює підвищений інтерес до зернобобових культур. Серед них особливої уваги заслуговує соя, площа якої з року в рік зростає [1].

У зв'язку із збільшенням посівних площ і поширенням сої в зону північного Лісостепу з більш вологим кліматом зростає загроза масового прояву хвороб на цій культурі. Установлено, що найбільш небезпечними хворобами тут є кутаста бактеріальна плямистість листя, пустульний бактеріоз, пероноспороз, септоріоз та аскохітоз.

Серед заходів боротьби з хворобами сої, як і інших культур найважливішими $є$ створення і впровадження в виробництво стійких до них сортів $[2,3]$. Цей захід $\epsilon$ найнадійнішим, економічно вигідним і найбільш перспективним [4].

Вивчення стійкості селекційного матеріалу сої дог патогенів важливо проводити на різних етапах селекції $[5,6]$. Першочерговим завданням $\epsilon$ знайти джерела стійкості до основних хвороб, оцінити стійкість сортів, запропонованих виробництву.

Мета і завдання досліджень. 3 метою пошуку джерел стійкості сої до основних хвороб упродовж 2004-2012 років нами проводилась оцінка ураженості рослин у колекційному і селекційних розсадниках відділу селекції і насінництва зернобобових культур та на інфекційному фоні відділу захисту рослин від шкідників і хвороб «ННЦ Інститут Землеробства НААН».

(C) С. В. Поліщук , С. І. Ляска. 2013.

ISSN 0582-5075. Селекція і насінництво. 2013. Випуск 103. 
Дослідження проводили у три етапи:

Перший етап - попередня оцінка ураженості хворобами сортів сої за умов природнього зараження впродовж декількох років. Це дозволяє виділити слабо уражені (з високою польовою стійкістю) сортозразки та значно скоротити об'єм робіт за штучного зараження патогенами. Матеріалом для дослідження служили різні за морфологічними ознаками, скоростиглістю та походженням 311 сортозразків сої світової колекції.

Первинний скринінг колекційного і селекційного матеріалу за ознакою стійкості до бактеріозів та інших хвороб проводився в розсадниках відділу селекції і первинного насінництва сої. а основна оцінка - в дослідах відділу захисту рослин.

Другий етап - основна оцінка стійкості зразків, виділених на попередньому етапі випробування. за ознакою польової стійкості в умовах штучного зараження високовірулентними штамами збудників основних бактеріальних хвороб (кутаста плямистість листя, пустульний бактеріоз), Зараження здійснювали в польових умовах шляхом ін'єкції бактеріальної суспензії в рослину (біб, стебло). Інфекційне навантаження 10 одиниць (1 млрд. клітин/мл). Оцінку ураженості проводили за чотирьохбальною шкалою згідно загальноприйнятої методики.

Оцінку стійкості досліджуваного матеріалу до пероноспорозу здійснювали на інфекційному провокаційному фоні. Для цього між досліджуваними номерами висівали сприйнятливий до хвороби сорт Подільська 416. А основна оцінка - в дослідах відділу захисту рослин.

Третій етап - контрольне випробування. Вивчається збереження ознаки стійкості при репродукуванні зразків виділених на другому етапі випробування, що забезпечує достовірність оцінки виділеного матеріалу.

Результати досліджень. За попереднього оцінювання спостерігалась велика різниця в ураженості сої залежно від сорту, фази розвитку рослини, від типу захворювань, особливостей їх збудників та погодних умов.

Наприклад, у колекційному розсаднику в 2012 році коливання ураженості хворобами становило від 1,0 \% до 99,3\%. Поширеність кутастої бактеріальної плямистості листя досягала 48,0 \% у сортів Вись, Алтом, Ас Brant, Ментор, Алтаip, №441, 514/08, Panda. Пустульним бактеріозом було уражено до $8,0 \%$, лише у семи досліджуваних сортозразків Вінничанка, Октябрська 70, 417/09, Сіверка, Вега, Кіровоградська 1, FM-55-22.

Також відзначено поширення грибних хвороб, зокрема пероноспорозу, до 93,3 \%. Найбільш ураженими виявились сорти Горизонт, Ватра Україна, Первенец, Скороспелка 3, К-11162 LF, Solano.

Серед колекційних сортозразків випробуваних у 2012 році за польовою стійкістю до пероноспорозу заслуговують уваги відносно стійкі сортозразки (ураженість до 10 \%) Северная звезда, Свана, Куйбишевська 77, Черемош, Юг-30 та інші. Без уражень бактеріозом відмічено сортозразки Harell, Смена, Хабаровська 12, Maple Hean, Brilmagerolla, Хвиля та інші. Ці 
сортозразки після повторного оцінювання ураженості в наступному році буде використано як вихідний матеріал у селекційній роботі.

За результатами вивчення стійкості колекційного і селекційного матеріалу сої впродовж 2004-2012 років відзначено високу польову стійкість (ураженість від $0 \%$ до $5 \%$ ) до бактеріозів і пероноспорозу у 32-х сортозразків (сорти Ланцетна, Елена, Чернятка Корада, Юг-40 та ін.; номери 441, 10311, 254 та ін.). У сприйнятливих сортів - Подільська 416, Даринца ураженість хворобами була в межах від 24,0 \% до 60,0 \% (табл. 1).

Таблиця 1

Польова стійкість сортозразків сої до хвороб, \%, 2004-2012 pр.

\begin{tabular}{|c|c|c|c|c|}
\hline \multirow{3}{*}{ Сортозразок } & \multicolumn{4}{|c|}{ Ураженість хворобами, \% } \\
\hline & \multicolumn{2}{|c|}{ Бактеріоз } & \multicolumn{2}{|c|}{ Пероноспороз } \\
\hline & $1 *$ & $2 * *$ & $1 *$ & $2 * *$ \\
\hline 1 & 2 & 3 & 4 & 5 \\
\hline Добруджанка 707 & $0-1,4$ & $0-0,4$ & $0-0,9$ & $0-0,1$ \\
\hline Ланцетна & $0-2,7$ & $0-0,7$ & 0 & 0 \\
\hline Gessoy & $0-2,9$ & $0-1,8$ & $0-1,5$ & $0-0,4$ \\
\hline Восход & 1,0 & 0,4 & 5,8 & 1,1 \\
\hline Лира & $1,9-3,5$ & 1,5 & 3,1 & 1,0 \\
\hline №441(Ходсон/Усур.) & 0 & 0 & 0 & 0 \\
\hline № 10311 & $0-6,0$ & $0-2,6$ & 0 & 0 \\
\hline Weber & $0-1,7$ & $0-0,7$ & $0-2,4$ & $0-0,5$ \\
\hline Закат & 2,3 & 0,4 & $0-4,9$ & $0-1,9$ \\
\hline Maple Presto & $0-1,7$ & $0-1,2$ & 5,4 & 3,0 \\
\hline Pickett & 4,0 & 0,9 & 5,6 & 1,2 \\
\hline Діона & 1,1 & 0,5 & 3,5 & 0,7 \\
\hline Березина & $0-3,1$ & $0-1,1$ & $0-2,8$ & $0-0,5$ \\
\hline Восток & $0-3,6$ & $0-1,7$ & $0-1,2$ & $0-0,3$ \\
\hline Фортуна & 2,5 & 1,2 & 2,3 & 0,5 \\
\hline Елена & 4,5 & 0,8 & 4,1 & 1,6 \\
\hline MON-10 & 2,3 & 0,6 & 6,1 & 1,1 \\
\hline Юг-40 & 8,4 & 1,9 & 2,7 & 1,2 \\
\hline Корада & 1,7 & 0,4 & 0 & 0 \\
\hline Северная звезда & 2,5 & 0,7 & 2,5 & 1,0 \\
\hline Рання 10 & $0-5,7$ & $0-1,2$ & 0 & 0 \\
\hline № 254 & $0-4,3$ & $0-2,0$ & $0-0,5$ & $0-0,5$ \\
\hline № 359 & 2,1 & 0,8 & 0 & 0 \\
\hline Вилия & $0-5,0$ & $0-2$ & $0-4,5$ & $0-1,5$ \\
\hline Подільська 416 & 24,0 & 12,0 & 53,3 & 25,3 \\
\hline Даринца & 60,0 & 18,0 & 50,0 & 26,0 \\
\hline
\end{tabular}


Продовження табл. 1

\begin{tabular}{|l|c|c|c|c|}
\hline \multicolumn{1}{|c|}{1} & 2 & 3 & 4 & 5 \\
\hline Хабаровська & 3,0 & 1,8 & 0 & 0 \\
\hline Прип'ять & 2,8 & 1,2 & 5,0 & 3,3 \\
\hline Плай & 4,3 & 0,8 & 4,5 & 2,9 \\
\hline Куйбишевська 77 & 5,4 & 3,1 & 2,5 & 1,7 \\
\hline Чернятка & 5,8 & 2,3 & 4,2 & 5,2 \\
\hline Київська 98 & 5,1 & 1,9 & 5,0 & 3,3 \\
\hline Примітка: * - - поширеність хвороби, 2**-розвиток хвороби \\
\hline
\end{tabular}

Відзначені сортозразки за основної оцінки підтвердили стійкість до збудників бактеріозів (пустульного і кутастої плямистості листя). За умов штучного зараження рослин рівень розвитку хвороб на виділених зразках був нижчим від сорту-стандарту Устя (2-2,5 бали) і становив 0,1-1,0 бали. Найнижчий рівень інфекції (0,1-0,3 бала) було відмічено на сортозразках Восход, Вилия, Ланцетна, Pickett, № 349, № 610.

При оцінюванні 16 перспективних селекційних номерів у 2009 і 2010 роках відмічено, що рівень їх ураженості хворобами за природного зараження був у межах: бактеріозами - від $0 \%$ до 25,0 \%, грибними хворобами - від $0 \%$ до 47,6 \% (табл. 2).

Таблиця 2

Ураженість хворобами

перспективних селекційних номерів сої, 2009-2010рр., \%

\begin{tabular}{|c|c|c|c|c|c|c|c|c|c|c|}
\hline \multirow{3}{*}{ Номер } & \multicolumn{6}{|c|}{ Бактеріоз } & \multicolumn{4}{|c|}{ Грибна хвороба } \\
\hline & \multicolumn{2}{|c|}{$\begin{array}{c}\text { пустульний } \\
\text { бактеріоз }\end{array}$} & \multicolumn{2}{|c|}{$\begin{array}{c}\text { кутаста } \\
\text { плямистість } \\
\text { листя }\end{array}$} & \multicolumn{2}{|c|}{ дикий опік } & \multicolumn{2}{|c|}{ пероноспороз } & \multicolumn{2}{|c|}{ септоріоз } \\
\hline & $1 *$ & $2 * *$ & $1 *$ & $2 * *$ & $1 *$ & $2 * *$ & $1 *$ & $2 * *$ & $1 *$ & $2 * *$ \\
\hline 1 & 2 & 3 & 4 & 5 & 6 & 7 & 8 & 9 & 10 & 11 \\
\hline $1-03$ & 0 & 0 & 0 & 0 & 0 & 0 & 0 & 0 & 0 & 0 \\
\hline $2-03$ & 4,5 & 1,8 & 0 & 0 & 0 & 0 & 2,3 & 0,2 & 0 & 0 \\
\hline $3-03$ & 8,9 & 2,5 & 0 & 0 & 3,7 & 0,8 & 6,7 & 1,8 & 3,7 & 2,2 \\
\hline 4-03 & 0 & 0 & 4,7 & 0,2 & 0 & 0 & 0 & 0 & 0 & 0 \\
\hline $5-03$ & 22,0 & 12,3 & 5,3 & 3,1 & 0 & 0 & 8,4 & 5,1 & 16,8 & 6,6 \\
\hline 6-03 & 6,5 & 5,2 & 16,6 & 8,1 & 20,0 & 12,2 & 10,0 & 4,3 & 0 & 0 \\
\hline $7-03$ & 25,0 & 7,8 & 0 & 0 & 0 & 0 & 7,1 & 5,7 & 0 & 0 \\
\hline $8-03$ & 7,0 & 4,1 & 0 & 0 & 32,5 & 12,5 & 9,2 & 3,5 & 0 & 0 \\
\hline $9-03$ & 7,0 & 1,3 & 3,2 & 0,5 & 25,0 & 13,6 & 3,6 & 0,7 & 0 & 0 \\
\hline $10-03$ & 12,3 & 6,5 & 3,1 & 0,9 & 2,6 & 0,3 & 0 & 0 & 13,2 & 7,2 \\
\hline 11-03 & 0 & 0 & 0 & 0 & 0 & 0 & 9,6 & 1,8 & 0 & 0 \\
\hline $12-03$ & 5,0 & 1,7 & 2,4 & 0,3 & 0 & 0 & 47,6 & 27,1 & 0 & 0 \\
\hline
\end{tabular}


Продовження табл. 2

\begin{tabular}{|c|c|c|c|c|c|c|c|c|c|c|}
\hline 1 & 2 & 3 & 4 & 5 & 6 & 7 & 8 & 9 & 10 & 11 \\
\hline $13-03$ & 1,5 & 0,9 & 15,6 & 3,1 & 1,5 & 0,6 & 0 & 0 & 0 & 0 \\
\hline $14-03$ & 5,7 & 2,1 & 25,0 & 10,0 & 0 & 0 & 11,1 & 1,1 & 2,6 & 1,1 \\
\hline $15-03$ & 0 & 0 & 8,3 & 4,6 & 0 & 0 & 12,0 & 4,8 & 0 & 0 \\
\hline $16-03$ & 6,4 & 2,4 & 25,0 & 10,0 & 0 & 0 & 7,8 & 0,8 & 0 & 0 \\
\hline \multicolumn{1}{|c|}{ Примітка: * 1 - поширеність хвороби, $2 * *$ розвиток хвороби } \\
\hline
\end{tabular}

Серед досліджуваних номерів кращим був 11-03, який у середньому за два роки не уражувався бактеріозами. Ураженість пероноспорозом була на рівні 9,6 \% за розвитку хвороби $1,8 \%$. Також слід відзначити номери 103, 2-03, 4-03 з високою польовою стійкістю до бактеріозів і грибних хвороб (ураженість від $0 \%$ до 5,0 \%). Стійкість до бактеріозів відзначені номери виявили також за умов штучного зараження виділеними нами високовірулентними штамами збудників пустульного бактеріозу і кутастої плямистості листя. Вони мали майже в чотири рази нижчий рівень розвитку інфекції (0,6-0,8 бали) порівняно із сприйнятливим сортом Устя (2,0-2,5 бали).

Висновки. 1. Найбільш розповсюдженими хворобами сої в зоні Лісостепу $є$ кутаста бактеріальна плямистість листя, пустульний бактеріоз, пероноспороз, септоріоз та аскохітоз.

2. Для оцінки стійкості до хвороб опрацьовано методику трьох етапної оцінки і відбору стійких форм у полі і на інфекційних фонах. Перший етап включає попередню оцінку ураженості хворобами сортів сої за умов природнього зараження впродовж декількох років. Другий етап - основна оцінка стійкості в умовах штучного зараження високовірулентними штамами збудників основних хвороб (кутаста плямистість листя, пустульний бактеріоз і ін..) зразків, виділених за ознакою польової стійкості на попередньому етапі випробування. Третім, завершальним етапом, є контрольне випробування, на якому вивчається збереження ознак стійкості при репродукуванні виділених форм.

3. У результаті імунологічної оцінки стійкості сої до хвороб серед досліджуваних сортозразків виділено 32 стабільно стійких до комплексу хвороб (бактеріальні та грибні) - №№ 254, 10311, 441,610 та інші і сорти, стійкі до бактеріозів - Ланцетна, Восток, Лира, Фортуна, Діона. Вони надалі будуть використані як джерела стійкості у селекційному процесі.

\section{Список використаних джерел}

1. Бабич A. О. Розробка і впровадження технології вирощування сої на зерно в умовах Лісостепу України / А. О. Бабич, В. Ф. Петриченко // Корми і кормовиробництво. - 1993. - Вип. 36. - С. 23-27.

2. Дяченко H. П. Агроценотические основы защиты зернобобових

Н. П. Дяченко // Защита растений. - 1988. - № 3. - С. 26-29. 
3. Картер Д. Агротехника сои / Д. Картер, Э. Хартвиг; Пер. с англ. М.: Колос, 1970. -167 с.

4. Стійкі сорти - радикальне вирішення проблеми захисту рослин / [C. О. Трибель, М. В. Гетьман, О. А. Грикун та ін.] // Захист і карантин рослин. - 2006. - Вип. 52. - С. 71-89.

5. Методические указания по изучению устойчивости сои к грибным болезням / [С. Н. Корсаков, С. И. Колесник, А. Я. Панасюк, Н. М. Петриченко]. - Л.: ВИР им. Н. И. Вавилова, 1979. - 19 с.

6. Соя / А. К. Лещенко, В. И. Сичкарь, В. Г. Михайлов, В. Ф. Марьюшкин. // Генетика, селекция, семеноводство. - Киев: Наукова думка, 1987. - 255 с. 